\title{
Beata KURYLOWICZ
}

Uniwersytet w Białymstoku beak@vp.pl

\section{ZAPOMNIANY ŚWIAT OBRZĘDOWOŚCI WESELNEJ W DAWNEJ POLSCE (NA PODSTAWIE SLOWNICZKA NAZWY WESELNE... ZYGMUNTA GLOGERA)}

W Encyklopedii staropolskiej Zygmunt Gloger tak oto tłumaczy, dlaczego obrzędy i obyczaje weselne uczynił tematem licznych opracowań etnograficznych: „Niepospolita doniosłość przedmiotu a zarazem gruba i naganna u inteligencyi polskiej nieświadomość jego piękna, jego przeszłości i znaczenia w obyczaju narodowym, a nadto idące $\mathrm{w}$ zapomnienie nawet wśród ludu pamiątkowe lechickich pradziadów obrzędy i pieśni, wszystko to skłoniło piszącego rzecz niniejszą, że od pierwszych lat swojej pracy naukowej sporo trudu i czasu poświęcił dla gromadzenia materjału etnograficznego w tym przedmiocie i dla spożytkowania tegoż bądź w kierunku naukowym, bądź dla podtrzymania w ludzie prastarej narodowej poezyi i lechickiego obyczaju" (Gloger: 1903 IV, 422).

Owocem dociekliwości badawczej podlaskiego starożytnika, a nade wszystko potrzeby ocalenia od zapomnienia leksyki godowej oraz ukrytej za słowami cząstki kultury polskiej i tradycji odchodzącej w przeszłość jest także słowniczek tematyczny Nazwy weselne, wyrażenia i przedmioty używane przy godowych obrzędach ludu na przestrzeni byłej Rzplitej, opublikowany w "Zbiorze wiadomości do antropologii krajowej” w 1877 roku. Leksykon ów zawiera obfity zbiór (ok. 240 ułożonych alfabetycznie haseł i znacznie więcej wyrazów, gdyż w jednym artykule hasłowym notowanych jest niekiedy kilka, a nawet kilkanaście jednostek leksykalnych) nieznanych bądź zapomnianych nazw, związanych z ludowymi obyczajami i obrzędami godowymi, pochodzących z różnych regionów Rzeczypospolitej. Taka konstrukcja słowniczka nie tylko umożliwia poznanie 
leksyki, która trafiła do językowego lamusa, ale pozwala także dostrzec cechy podobne czy nawet stałe w obchodach weselnych, jak i pewne rozbieżności wynikające ze zróżnicowania terytorialnego i językowego dawnej Polski.

Przedstawiona w szkicu analiza słownictwa, pochodzącego z pracy Glogera ${ }^{1}$, ma za zadanie $\mathrm{z}$ jednej strony przybliżyć dawną leksykę weselną, z drugiej natomiast - pomóc w odtworzeniu ukrytej za słowami bogatej obrzędowości godowej, żywej jeszcze w drugiej połowie XIX wieku, a dziś niemal całkowicie zapomnianej. Celem artykułu nie jest jednak drobiazgowy opis lingwistyczny słownictwa weselnego, na co nie pozwalają ograniczone ramy artykułu, lecz zasygnalizowanie możliwości, jakie stwarza analiza leksemów zanotowanych w słowniku. Bliższe przyjrzenie się leksyce weselnej z perspektyw dialektologicznej i diachronicznej, co stanie się przedmiotem dalszych dociekań naukowych, pozwoli z pewnością sformułować ważne i inspirujące wnioski. W tym szkicu chciałabym jednak zwrócić uwagę na aspekt kulturowy i pokazać słowniczek tematyczny jako wartościowe źródło do poznania dawnej tradycji. Skonfrontowanie materiału słownikowego z danymi etnograficznymi ma dowieść wiarygodności dzieła Glogera.

Zgromadzone przez Glogera wyrazy można podzielić na kilka grup znaczeniowych, niniejsze rozważania zacznijmy jednak od nazw ogólnych, do których należą określenia nazywające uroczystość weselną, pełniącą w kulturze ludowej niezwykle ważną funkcję społeczną: akt weselny / acht weselny (na Kujawach) 'uroczystość a nawet zgromadzenie weselników $(. . .)^{\prime 2}$, biesiada i beseda 'często używana przez lud nazwa wesela. Gdy na Ukrainie weselnicy nazajutrz po ślubie obchodzą z hulanką chaty, to mówią, że chodzą po besedzie', wesele, weselisko, weselicko, wesile 'na Rusi południowéj a wiasiele na białéj; w Wielkopolsce wesela zowią w l.mn. wesołami' oraz metaforyczne określenie ślubu: kobierzec ślubny 'poprowadzić na kobierzec i od kobierca, iść na kobierzec i t. p. znaczy to samo co do ślubu i od ślubu'. Sfrazeologizowana konstrukcja wyjść za mąż to po litewsku teku aż wira, co dosłownie zna-

1 W szkicu prezentuję wszystkie zgromadzone przez podlaskiego leksykografa wyrazy.

2 Znaczenia prezentowanej leksyki, zaczerpnięte z definicji utworzonych przez Glogera, podaję w łapkach. Gdy definicja jest rozbudowana, informacje o charakterze encyklopedycznym wprowadzam, stosując cudzysłów. Takie rozwiązanie z jednej strony pomaga zachować oryginalny charakter słowniczka, z drugiej natomiast służy konfrontacji danych pozyskanych przez Glogera z faktami ustalonymi przez badaczy kultury polskiej. 
czy „pociec za mężem” - zaznacza Gloger. Dzień ślubu z kolei nazywano szlubowinami. Wesela odbywały się $\mathrm{w}$ domu panny młodej, określanym jako weselny dom lub stare miejsce, stare kukrzysko. K. Kwaśniewicz zauważa, że: „ślub bez wesela był czymś, co nie mieściło się w mentalności chłopskiej. Związek małżeński nie poparty społecznym wymogiem wyprawienia wesela zasługiwał w opinii ogółu na kpiny i pogardę (...)" (Kwaśniewicz 1981: 91).

Liczną grupę wyrazów, wynotowanych ze słowniczka, stanowią nazwy uczestników wesela, w tym ogólne: weselnik (w l.mn. weselniki) oraz drużyna weselna, którą tworzą 'wszyscy w ogóle weselnicy i goście, a mianowicie orszak pana młodego i panny młodéj, zaproszeni gospodarze i gospodynie, drużbowie i druchny' - pisze Gloger. Wybór gości, których zapraszano trzy razy i przeznaczano im określone role, odbywał się bardzo starannie. Obecność konkretnych osób mogła bowiem uświetnić ceremonię, ale mogła również ośmieszyć nie tylko ich samych, ale i obrzęd (Ciołek, Olędzki, Zadrożyńska 1976: 38). Ślub i wesele przyciągały tłumy gości, ponieważ postrzegano je jako okazję „do zademonstrowania solidarności i koligacji rodzinnych i sąsiedzkich", poza tym jako okazałe, barwne widowisko, które przerywało monotonię dnia codziennego, dawało sposobność do nawiązania kontaktów towarzyskich, a w niższych sferach stanowiło „rzadką okazję najedzenia się do syta przysmakami z obficie zastawionych stołów". Na wiejskie wesele, aby dodać ceremonii splendoru, „schodziła się cała gromada, a przy okazji zapraszano także urzędników dworskich, wójta czy sołtysa, karczmarza, kościelnego, bakałarza, plebana - słowem całą wiejską elitę" (Bogucka 1994: 50).

W uroczystościach weselnych, które trwały kilka dni, a mogły przeciągnąć się nawet do kilku tygodni (Ciołek, Olędzki, Zadrożyńska 1976: 34), najważniejszą rolę odgrywali oczywiście państwo młodzi (w Poznańskiem młodzieńcowie lub młodziankowie), czyli - jak wyjaśnia autor słowniczka - panna młoda i pan młody od chwili ślubu. Na określenie panny młodej w dziewiętnastowiecznej polszczyźnie ludowej funkcjonowało wiele uwarunkowanych geograficznie nazw. Są to głównie sufiksalne formacje słowotwórcze z rdzeniem młod- (prsł. * mold-) i ich warianty fonetyczne (najczęściej z pełnogłosem, wskazującym na ich wschodniosłowiański rodowód): młoducha, mołoducha, młoda, mołoda, mołodzica, maładzica (na Biełéjrusi), mołodyca, mołodycia, młodzica, młoduszka (u górali tatrzańskich), młodzieńcowa (w Poznańskiem); zestawienia młoda pani (na 
Kujawach), pani młoda (na Szlązku); a także marti (na Litwie), domacha, kniahini, królewna, koroliwna, sużenaja ${ }^{3}$.

Młody pan (na Kujawach), kniaź, król, sokót, sużenyj to z kolei nieliczne określenia odnoszące się do pana młodego. Gloger odnotował także słowo prymak (przyjmak), używane nad Berezyną na określenie nowożeńca, „który nie mając chaty i własnéj gospodarki, zamieszkuje w domu swéj żony lub jéj rodziców".

W orszaku panny młodej znajdowały się niezamężne krewne i przyjaciółki, czyli druchny, druchniczki, drużki, drużeczki, panny drużbiące (w dawnej polszczyźnie), balszanki na Rusi swaszki i swachny w Galicji. Spośród druhen panna młoda wybierała starsza druchne ,jeżeli nie siostrę to najbliższą z przyjaciółek i najroztropniejszą, świadomą dobrze pieśni i obyczaju, która czuwa nad czystością w izbie i zwykle ubiéra pannę młodą do ślubu, zwana ztąd ubierackq (u Kurpiów)". Pozostałe druhny są "młodszemi, zwane także swachnami (nad Sanem i Wartą), pod-drużkami (pid-drużka) nad Dniestrem, przydankami w dawnej polszczyźnie (...), prydankami na Rusi". Niezamężne siostry pana młodego były z kolei jego druhnami.

Słowniczek Glogera poświadcza także leksemy drużba, druzba, druzebka, drużko odnoszące się do nieżonatych mężczyzn tworzących orszak pana młodego. Na Litwie drużbowie nazywali się broléj, czyli bracia, na Rusi zaś - bojarowie. Gloger tłumaczy, że: „Nazwę tę spowodowała pewna cecha rycerskości i dostojeństwa drużbów weselnych, występujących w orszaku konno, niby rycerze, szlachta i istotni bojarowie". W Zapuszczańskiem (także na Litwie) drużba to draugas.

Starszy drużba, którego obowiązkiem było czuwanie nad całością obrzędów weselnych (Kwaśniewicz 1981: 93), nosił niekiedy nazwę marszałka lub stanowniczego (w Jasielskiem ${ }^{4}$ ), młodsi natomiast zwani byli przydankami, namiestnikami, młodzieńcami i poddrużkami (na Rusi pid-drużbyk, pid-drużko, pod-druży). W Sandomierskiem, Lubelskiem i na Rusi drużba starszy i młodszy to chorąży i podchorąży.

3 Sużenyj, Sużenaja (sądzony, sądzona) 'tak pieśni ukraińskie zowią nowożeńców (...), co przypomina przysłowie: „mąż i żona od Boga sądzona” tudzież nazywanie narzeczonych bogdankami'.

4 W Jasielskiem stanowniczy, trzymając białą chorągiewkę, przewodził konnemu orszakowi, jadącemu do ślubu. 
W Sandomierskiem do orszaku weselnego należał także drużba proszak, prosak, którego zadaniem było zapraszać na wesele i „wzywać weselników o podarki dla młoduchy". Gloger dodatkowo wyjaśnia: „Gdy panna młoda zaprasza na wesele, mówią, że poszła na proszaki".

Ważnymi postaciami weselnymi byli tzw. urzędnicy, wśród których wyróżniał się starosta 'najstarszy dostojeństwem urzędnik, gospodarz weselny, zwykle bywa nim swat. W Krakowskiém zowią go także starym: widzimy go na Kujawach, (...) w Jasielskiém (...); na Pińszczyźnie bywa i podstarości; nad Dniestrem dwóch: ze strony panny młodéj starosta dański, czyli ten, który daje żonę panu młodemu i starosta brański, który dla niego bierze, zwany także bojarskim'.

Żona starosty weselnego była zazwyczaj starościna, czyli pełniła funkcję gospodyni weselnej i przewodniczyła niektórym obrzędom.

Do grona urzędników weselnych, według Glogera, należeli także marszałek (marsałek, marszałok) 'jeden ze starszych urzędników weselnych, niby mistrz ceremonii, dozorca porządku obrzędowego. Tytuł marszałka nosi zwykle jeden z gospodarzy lub starosta weselny, a spotykamy go na Litwie, Żmudzi, Rusi i u ludu polskiego niektórych okolic. (...)', pysar 'wrzekomy urzędnik weselny niekiedy na Rusi czerwonéj „kotryj prybywajuuczych Bojaryw, ich koni, wozy tym podobnnyi riczy spysuje", (Ruskoje wesile)', sendzia (sędzia) 'wrzekomy na Rusi czerwonéj urzędnik weselny, "kotryj wydarajuczysia sprawy i neshody sudyt" (...)' oraz miczała, konowat 'urzędnik w niektórych okolicach, zwłaszcza na Rusi czerwonéj, obiérany w celu, a by przeprowadzał gości, gdy który z trunku i jadła zachoruje i układał w spokojném miejscu takich, coby zamroczeni trunkiem przespać się pragnęli. Ztąd téż jest i przysłowie, kiedy ktoś do niczego niezdatny: „daj go miczale"'.

W czasie uczty weselnej w niektórych regionach dawnej Polski osobą odpowiedzialną za rozlewanie trunków był czasznik 'podczaszy weselny w niektórych okolicach Rusi'.

Ważną postacią na weselu był grajek, muzyka 'grajek na białéj i litewskiéj Rusi, zwykle przyjaciel lub krewny pana młodego', wesotek, wesołko, wesołka, wesotuch u ludu polskiego, a wiesiołek, wiesiotko u rusińskiego 'skrzypek, piérwszy grajek weselny, wysokie stanowisko i szacunek $w$ hierarchii godowéj posiadający. W Sandomierskiém powiada Kolberg: „,wesołuchowi” cześć prawie oddają (...)'. Na standardowym weselu grała muzyka, ale zdarzały się także wesela ciche, bez muzyki. Na Pogórzu Nadrabskim określano je jako wesela we worku, ponieważ "gości 
na nich bardzo mało - stąd ta ich nazwa. Z ludzi bowiem na takie wesele zaproszonych wyśmiewają się, że jest ich tak szczupła liczba, iż można ich wszystkich do worka zebrać. Wesela te zdarzają się jedynie u ludzi biednych - komorników" (Świętek 1893: 163-164).

$\mathrm{Na}$ tradycyjnym weselu nie mogło zabraknąć oratora, w niektórych regionach nazywanego mowista 'tak mowców i oratorów weselnych nazywa pieśn obrzędowa z nad Prypeci (...)' lub rzeczakiem 'mówca weselny u górali tatrzańskich (ob. Mowista)'. Mówca weselny wygłaszał orację, czyli mowę prozą lub wierszem. Na weselach chłopskich oracją starosta weselny witał nowożeńców wracających z kościoła (zob. Kuchowicz 1975: 194). Z zapisków Glogera wynika jednak, że oracje wygłaszano również w innych okolicznościach: oracyja „(...) Oracyją zaprasza starszy drużba gości na gody w Wielkopolsce; przy oracyi otrzymuje panna młoda wieniec przed ślubem i oracyją ktoś z jéj strony podziękować zań musi, jeżeli zaś zdarzy się, że nikt nie umié, to ten sam orator, który od pana młodego wieniec ofiarował, przechodzi na jéj stronę i dziękuje mową zwaną ztąd podziękowaniem. W wielu okolicach po uczcie weselnéj jeden z gości dziękuje oracyją. Mowy takie bywają nieraz żartobliwe. Nad Narwią ofiarowanie wieńca przy stosownej oracyi zowie się udaniem wieńca (ob. Mowista, Rzeczak)".

O pomyślny przebieg uroczystości dbał także woźnica weselny, którego na Litwie nazywano: keleweże, mart, weżys. Z kolei na Rusi do osób zaangażowanych w przygotowanie uczty należeli korowajnica i korowajnik 'przyrządzają na Rusi obrzędowe ciasto, a są i pieśni (np. na Wołyniu) do starszéj korowajniczki (...').

$\mathrm{Na}$ wesele zapraszano także swata, który pełnił istotną funkcję podczas wstępnych etapów wesela. Gloger tak opisuje jego rolę: „Zwykle, gdy ciche swatanie i zwiady zostaną dopełnione pomyślnie przez kobiéty, wtedy młodzian wybiera statecznego gospodarza na swata, który idzie z nim prosić o rękę dziéwki, targować się z jéj rodzicami o wiano, ułożyć czas wesela i plany do nowego stadła na przyszłość. Gdy nastąpią gody, swat zostaje piérwszym urzędnikiem t.j. starostą weselnym, którego rozkazy w domu i obrzędach wszyscy ściśle wypełniają. Ta obrzędowa dostojność swata i starosty (wobec której niknie powaga rodziców państwa młodych), zdaje się być zabytkiem odległych czasów odziedziczonych wprost po weselnych kapłanach pogańskiej Słowiańszczyzny". Zależnie od regionu swat różnie był nazywany: „swak (w Krakowskiém), po litewsku pirszlis - swat, pirszle - swacia (...), na Żmujdzi swotas, a ponais 
swatoi - panowie swacia (...). Zdaje się, że pirszlis i swotas odziedziczyli swoje obowiązki po szwalgonie, który miał być weselnym kapłanem dawnych Litwinów i zamieniał nowożeńcom pierścienie na znak ślubu. W Augustowskiém swat nazywany jest częściéj rajem, a nad Narwią rajkiem, w innych stronach dziewosłębem (ob.)". Z materiałów Glogera wynika, że osobą kojarzącą małżeństwo mogła być także kobieta: swatka 'dziewosłębina, zastępuje często na Kujawach swata przy oświadczynach (...)'.

Źródła etnograficzne dowodzą, że udział swatów stanowił zwyczajową formę zawierania umowy małżeńskiej, aczkolwiek szczególną rolę przypisywano im w środowisku zamożnych rodzin gospodarskich, których majątek - wedle powszechnej opinii - nie powinien być narażony na straty z powodu nieodpowiedniego wyboru partnera (Kwaśniewicz 1981: 92).

Godne miejsce na weselu zajmowali babka ‘Na Białéj-Rusi do drużyny weselnéj należy i babka panny młodéj, czyli stara kobiéta, starnica, która spełniała usługe przy jéj narodzinach' oraz woziło 'ojciec chrzestny pana młodego u ludu nad Berezyną (że woził go do chrztu), ma przeznaczone przy uczcie weselnéj starsze miejsce na końcu stołu, (...)'.

Swoją obecnością ceremonię uświetniali również krewni państwa młodych. Gloger wymienia tu, niestety, zaledwie kilka nazw: dziewierz (u ludu polskiego), dziewier (u Rusinów) 'szwagier, brat pana młodego (...)', mosza (litew.), śwityłka, załwica, 'szwagierka, siostra pana młodego i w ogóle mężowska (...)', pani matka 'matka panny młodéj lub pana młodego', snycka 'synowa u Kurpiów (...)'.

W dawnej polszczyźnie istniało wiele wyrazów określających mężatkę uczestniczącą w uroczystościach weselnych: swacha, swaszka, swaczka, swachna, swachniczka (w pieśni); swańka, swaneńka (na Rusi); swoka (na Litwie tudzież w Krakowskiem). Wyróżniano swachy starsze i młodsze, te ostatnie „wybrane do pewnych obrzędów i czynności zowią się w niektórych okolicach Rusi prydankami, do nich należy pieczenie ciasta obrzędowego". Z kolei lud galicyjski - dodaje Gloger - swaszkami i swachnami niekiedy nazywa druhny. Do grupy nazw kobiet można zaliczyć także słowa perezwanka 'każda mężatka lub dziéwka zaproszona na wesele w Pińszczyźnie. (...)' oraz białka 'skrócenie wyrazu białogłowa. Tak Kurpie mazowieckie nazywają mężatki (...)'.

Interesującym wyrazem, dającym wyobrażenie o dawnej etykiecie weselnej w regionie mazowiecko-podlaskim, jest zasadka 'mała dziewczyna w niektórych okolicach Podlasia i Mazowsza posadzona przy 
uczcie weselnéj na szarym końcu stołu, gdzie nikt z dorosłych bez ubliżenia swéj godności usiąść nie może, ani téż miejsce puste przy stole godowym być powinno'.

Gloger notuje również inne ciekawe nazwy osób związanych z obyczajami godowymi: maczucha 'u Rusinów galicyjskich baba lub chłopiec przebrany i zakryty, którego pokazują panu młodemu w miejsce jego narzeczonéj, gdy ta wydali się na wieś spraszać gości (...) Podobny zwyczaj $\mathrm{z}$ pewnemi odmianami istnieje $\mathrm{u}$ nas prawie wszędzie', grabarze 'na Kujawach swawolni chłopcy, którzy z łyżkami na sznurkach u pasa zawieszonemi, wpadają do izby, gdzie się warzy obiad weselny i chwytają z garnków co mogą na łyżki, wetując sobie zawczasu ucztę, w któréj malcy nie biorą udziału (...)' oraz zaporożcy 'swawolni chłopcy na Wołyniu, którzy (jako dzieci) nieprzypuszczeni do stołu weselnego, kołaczą do drzwi izby godowéj i dostają smaczne kąski (...)'.

W przedmiotowym słowniczku zostały poświadczone również leksemy nazywające dziewczynę gotową do zamążpójścia: tatokas 'litew. dziewka na wydaniu' oraz młodego mężczyznę starającego się o rękę dziewczyny: żenikas 'litewsk. zalotnik, kawaler, konkurent, młodzian proszący o rękę dziéwki'.

Nazwy osób ściśle wiążą się z leksyką nazywającą czynności i działania, układające się w cykl tradycyjnych zwyczajów weselnych, które w polszczyźnie ludowej określano mianem obrządków weselnych. Model wiejskiego wesela z XIX wieku składał się z dwóch podstawowych członów: zmówin, obejmujących wstępne fazy wesela, czyli zwiady, swaty i zaręczyny, oraz zdawin, w których zawierały się zwyczaje stanowiące istotę aktu zaślubin (Kwaśniewicz 1981: 92). Gloger notuje bogaty zbiór nazw należących do tej kategorii semantycznej.

Wstępny etap zwyczajów weselnych rozpoczynały zwiady, dowiedziny (na Mazowszu) acikłauść (na Litwie), polegające na wysłaniu przez młodzieńca przychylnej sobie, zręcznej i statecznej niewiasty - jak wyjaśnia Gloger, aby wybadała rodziców upatrzonej dziewczyny. Gloger tłumaczy, że podczas zwiadów dokonywano także oględzin, zwanych też oględami, opatrami, przegladami (w Poznańskiem). Był to: „Zwyczaj oglądania gospodarki, mienia i domostwa, bądź wzajemnie dopełniany przez swatów lub rodziców, bądź z jednéj strony przed deklaracyją ${ }^{5}$ lub po deklaracyi, w miarę uznania potrzeby lub wymagań miejscowéj tradycyi". Po

5 Deklaracyja (zmówiny, zapoiny) 'przyrzeczenie dziéwki młodzianowi przy swatach'. 
pomyślnych zwiadach następowały swaty, nazywane też zalotami (na Mazowszu), zapytankami (w Poznańskiem), zapoinami małymi (na litewskiej Rusi), zrainami lub oświadczynami, które sprowadzały się do zawarcia umowy małżeńskiej przez pośredników - swatów wysłanych przez konkurenta. W słowniku Glogera poświadczone są nazwy czynności związane z obowiązkami swatów: swadźba, swatanie, swatostwo, swactwo, rajenie (autor nie eksplikuje znaczeń tych wyrazów), ponadto przywołane są dwa bezokoliczniki należące do tej kategorii semantycznej: raić, wyraić 'swatać, wyswatać'. Interesujący wydaje się tu być termin swadźba, którego Gloger nie definiuje. W drugiej połowie XIX wieku miał on trzy znaczenia: 'wesele, gody weselne', 'swaty, swatanie, swatostwo, rajenie', a także 'drużyna weselna' (SW VI: 523-524). W. Abraham podaje, że słowo to jest najstarszym określeniem zawarcia małżeństwa, wspólnym wszystkim językom słowiańskim (1925: 57). Na podstawie odnotowanych wariantów słowotwórczych można jednak przypuszczać, że w zamyśle Glogera termin ten miał oznaczać w przedmiotowym słowniku 'swaty'.

Aktem obrzędowym zatwierdzającym umowę małżeńską zawartą za pośrednictwem swatów były zaręczyny, stanowiące w przeszłości świecką formę zaślubin (Tymochowicz 2013: 194). Gloger definiuje je następująco: „Po pomyślnych swatach i zmówinach następują zaraz zaręczyny, czyli obrzęd zamiany pierścionków lub rąk wiązania. Swat przybywając z młodzianem przynosi z sobą wódkę (tak jak do oświadczyn), a ztąd: iść na zaręczyny zowie się po litewsku su ariełkom (z gorzałką), lubo same zaręczyny mają nazwę użgiarsztojes (...). Wiązanie rąk narzeczonych na podgórzu karpackim zowie się rękowaniem". Autor podaje także kilkanaście określeń zaręczyn pochodzących z różnych regionów dawnej Rzeczypospolitej: „rękowiny w Krakowskiém i w ogóle na Podgórzu zrękowiny, na Kujawach zdawiny, pierśsionki i pierścianki, w obw. Boreckim zrędziny, na Rusi zapoiny wielkie, zaruczyny, zrukowyny, rukowyny, wielika horełka, w pieśni białoruskiej zaruczynki". K. Kwaśniewicz traktuje zaręczyny i zmówiny jako jeden obrzęd (1981: 93), z kolei z obserwacji Glogera, odzwierciedlonych $\mathrm{w}$ słowniczku, wynika, że w niektórych regionach zmówiny były odrębnym obyczajem: „Zmówiny na Kujawach, Białéjrusi i niektórych stronach innych, oznaczają naradę nad losem i sprawami kojarzącego się stadła. Bywają zwykle po zaręczynach w domu rodziców dziéwki lub w gospodzie, jeżeli noszą tradycyjny charakter narady całego sioła". 
Po zaręczynach zaczynały się obrzędy zwane zdawinami ${ }^{6}$. Przygotowania do wesela trwały zwykle około czterech tygodni, a inicjowały je zapowiedzi (Kwaśniewicz 1981: 93), o których podlaski starożytnik nie wspomina. W Glogerowych zapiskach odnotowane są natomiast sprosiny 'na Rusi sprosyny, na Pińszczyźnie także perezwa, zapraszanie gości na gody weselne, co uskutecznia w niektórych stronach panna młoda, $\mathrm{w}$ innych drużbowie przy stósownych oracyjach'. Gloger dodaje, że w Krakowskiem panna młoda, zapraszając gości, rozdaje dzieciom malutkie kukiełki zwane osutkami lub rozsutkami.

$\mathrm{W}$ wielu regionach Polski przed weselem panna młoda odwiedzała sąsiadów, którzy obdarowywali ją różnymi prezentami na poczet przyszłego gospodarstwa. Zwyczaj ten nazywał się wspomożenie panny młodej 'stare prawo zwyczajowe naszego ludu, wedle którego całe sioło i wszyscy krewni darzą czyli składają się na wiano i nowe gospodarstwo idącéj za mąż dziéwki. Podarkami są różnolite przedmioty, jak: len, zboże, płótno, sukno, owce, cielęta, piéniądze i t.d. Panna młoda przed weselem odbywa rodzaj kwesty, czyli jak tu i owdzie nazywają „chodzi po wspomożeniu" (ob. Lnowalne). Składanie darów stanowi także w wielu okolicach oddzielny obrzęd w czasie godów' lub lnowalne, chodzić po lnowalném 'na Podlasiu panna młoda obchodzi całą wieś kwestując len, a każda gospodyni darzy ją zwitkiem na nowe gospodarstwo, wedle bowiem starego prawa zwyczajowego, całe sioło ma obowiązek wianować każdą dziewicę. (...)'.

W przeddzień ślubu odbywał się dziewiczy wieczór lub dziewic wieczór, czyli ‘ostatni wieczór przed ślubem t. j. ostatni wieczór dziewictwa panny młodéj, uroczyście obchodzony przez jéj pokrewne dziéwczęta i przyjaciółki, które tańczą i wiją wieńce przy śpiewaniu stosownych pieśni. Jest to początek wesela. Na Białéjrusi dziwicz wieczar (...) na Ukrainie dewicz weczer i diwycz weczor (...); na Rusi podlaskiéj zlubiny; na Litwie mergu makaras (...)'. Wieczór przedślubny to zatem czas, który panna młoda spędzała $\mathrm{w}$ domu rodzinnym $\mathrm{w}$ towarzystwie druhen i rówieśniczek, wijących wieniec weselny i rózgę weselną. Wieniec weselny nazywane w polszczyźnie ludowej wieńcem, wiankiem, wianuskiem, wianuseckiem lub wianeckiem Gloger definiuje następująco: 'godło dziewictwa a ztąd jako korona umieszczany na głowie dziewicy idącéj za mąż, przemienił się téż w wielu okolicach na „koronę” ze świecideł. (...) Koło Krakowa pan

6 Gloger nie używa nazwy zdawiny w tym znaczeniu. 
młody daje swéj narzeczonéj i druchnom „na wianki”, które (ze świecideł) kupuje się gotowe dla wszystkich dziéwek mających uczestniczyć w weselu'. Z kolei rózga weselna to 'znak symboliczny, drzewo życia, w różnych stronach odmienną mający postać i rozmaicie nazywany: Na Kujawach jabłonka jest gałęzią cierniową w jabłka, pierniki, ciastka i orzechy przybraną (...). Na Podlasiu wianek lub krzak jest gałęzią jałowca lub jodły, na któréj starszy drużba wiezie i wręcza pannie młodéj od narzeczonego wieniec i chustkę w podarku. (...). Na Ukrainie wilce jest to młoda sośninka, do której gałązek parobcy bukiety z kaliny, owsa i barwinku, i którą zatykają w chléb weselny (...). W innych stronach Rusi wiłeczko, derewce i t.d. W Sandomierskiém rózga weselna (...)'.

W niektórych regionach dawnej Polski w dzień przed ślubem miało miejsce ogrywanie wieńców lub druchen. Był to: 'zwyczaj w Krakowskiém chodzenia weselnéj kapeli $\mathrm{w}$ przeddzień ślubu i grania po domach wszystkich druchen, które za to częstują muzykantów; ostatni bowiem dzień przed ślubem jest uroczystością dziewic (ob. Dziewiczy wieczór)'.

Z wieczorem dziewiczym wiązał się także stary, zanikający w drugiej połowie XIX wieku zwyczaj zwany rozplecinami, które uchodziły za jeden z najistotniejszych obrzędów przedślubnych (Kwaśniewicz 1981: 96). Uzmysławiał on przejście do innego stanu społecznego, cywilnego, innej grupy wiekowej, a także podporządkowanie władzy mężowskiej (por. Potkański 1895: 348-349; Abraham 1925: 221-235). Gloger tak oto definiuje rozpleciny: 'uroczyste rozplecenie włosów pannie młodéj przed wyjazdem do ślubu. W obrzędzie tym główną rolę gra starszy jéj brat jako stróż przyrodzony cnoty siostrzanej, której symbolem jest kosa (warkocz). Mężatki bowiem nie nosiły warkocza, który obcinano im po ślubie, tak nad Wisłą jak nad Niemnem, gdzie obrzęd postrzyżyn weselnych zwał się pakirptimas, (...)'. W słowniku zostały umieszczone także wspomniane wyżej leksemy kosa 'warkocz dziewiczy, którego mężatki nie nosiły, a ztąd symbol dziewictwa i obrzęd uroczystych rozplecin przed ślubem, po którym ucinano kosę młodusze, zostawiając kędziory. W Krakowskiém dziéwczęta splatają zwykle włosy w jedną kosę, a na Rusi i Mazowszu we dwie' oraz kędry (kędziory) 'tak lud sandomiérski zowie włosy u mężatek przycięte na karku. Pannie młodéj po ślubie obcinają kosę, (ob.) zostawiając kędry (....'.

W wigilię ślubu starsze gospodynie piekły ciasto weselne, które w Polsce zachodniej nazywano kołaczem, a we wschodniej korowajem. Gloger notuje obie nazwy: kołacz 'placek weselny, obrzędowe ciasto z mąki 
białéj, dziś u ludu (polskiego), a dawniéj u wszystkich stanów. (...) Na Podlasiu, wschodniém Mazowszu i w Lubelskiém przechodzi nazwa kołacza w korowaj, (ob. Korowaj, Pruzyk)'; korowaj 'ciasto obrzędowe na Rusi, Litwie, tudzież u ludu polskiego na Podlasiu, w części Mazowsza i w Lubelskiém. W Łomżyńskiém cząstkowa szlachta i chłopi piekli korowaj, również jak w Lubelskiém. Na Litwie właściwéj korowaj zowią karwòjus, karwòjaus, korowajus. Karwòjaus tupinieć, znaczy korowaj rozrywać, łupić, co bywa przy podziale ciasta między weselników. $\mathrm{Na}$ Białéjrusi pieką kilka korowajów, z których główny zowie się pierapieczą. (...) Ozdabianie tego ciasta jest wszędzie główną jego charakterystyką. W niektórych okolicach pan młody i panna młoda mają oddzielne korowaje'. W innym miejscu słowniczka autor rejestruje nazwy gaska, huska, kaczka, które objaśnia jako 'ptaszki z ciasta, któremi ozdabiają korowaj'. Wypiekanie ciasta weselnego miało uroczysty, obrzędowy charakter. Korowaj traktowany był bowiem jako dar Boga-Ojca, Jezusa Chrystusa, Najświętszej Panny. Symbolizował płodność i urodzaj (Bączkowska 1998: 79-80).

Z korowajem łączyły się inne zwyczaje, przykładowo pod hasłem kroska Gloger notuje: 'kukiełka, piérożek, wyskróbka, którą u ludu nad Berezyną każdy mieć musi z biorących udział w pieczeniu korowajów (...)', i czynności rytualne: mienianie korowajów 'na Biełéjrusi obrzęd zamiany dwóch korowajów państwa młodych dokonywany przez ich ojców chrzestnych; (...)'. Ze względu na szczególne znaczenie symboliczne korowaja regionalne zwyczaje charakteryzowało bogactwo czynności i zachowań rytualnych, zwłaszcza podczas podziału i spożywania tego pieczywa, czemu towarzyszyło obowiązkowe uroczyste skupienie (Kwaśniewicz 1981: 102).

Wieczór przedślubny kończył się śpiewem na dobranoc. W artykule hasłowym dobranoc Gloger podaje: ",Śpiewać na dobranoc”. Są oddzielne pieśni „na dobranoc”, które weselnicy zawodzą opuszczając dom panny młodéj wieczorem lub w nocy (...)'.

Dzień ślubu zaczynał się od grania na dzień dobry. Gloger w definicji wyrazu hasłowego dzieńdobry, dzieńdobre " "chodzić po dzieńdobrém”, znaczy na Mazowszu i Podlasiu gdy weselnicy z kapelą odwiedzają po kolei domy gospodarzy uczestniczących w uroczystości weselnéj, co ma miejsce od rana przez kilka dni poślubnych (ob. Biesiada)' zaznacza, że był to zwyczaj mazowiecko-podlaski, z kolei K. Kwaśniewicz podaje, że na dzień dobry grano także w Krakowskiem (Kwaśniewicz 1981: 97). 
Przed wyjazdem do ślubu miały miejsce przeprosiny 'gdy przy wyjeździe do ślubu panna młoda przeprasza rodziców swoich, rodzeństwo i pokrewnych, a ci ją błogosławią' oraz udanie wieńca 'w okolicach nadnarwiańskich ofiarowanie go uroczyste przy stósownej oracyi w imieniu pana młodego pannie młodéj przed wyjazdem do ślubu'.

Młodą parę po zaślubinach witano w szczególny sposób. Gloger przywołuje tu określenie kosmato witać, czyli 'podawać rękę przez połę, sposób winszowania nowego małżeństwa. Tak witają wszyscy nowożeńców po ślubie'.

Podczas uczty weselnej nowożeńcy zajmowali specjalnie dla nich przygotowane miejsce, które nazywano posah, posad 'prowadzić na posad, uroczyste miejsce zwykle na pokuti (pokąciu) w rogu izby za stołem, zasłane kożuchem, gdzie lud na Rusi ceremonialnie sadowi nowożeńców do obrzędów i uczt'.

Najważniejszym momentem obrzędowym wesela były oczepiny 'czepiny w Poznańskiém; kapiny i okapiny na Kujawach (...); zaczepiny w Krakowskiém; czepczyny i powjazany na Rusi czerwonéj (...) skrywanie lub pokrycie namitka i oczepkiem, na Ukrainie i innych Rusiach. Uroczyste przy stósownych pieśniach i obrzędach włożenie na głowę panny młody [sic!] po raz piérwszy ubioru mężatki'. Gloger ponadto notuje czepczyny, czepiny, cepiny, cepienie, ob. Oczepiny' oraz powiwaty, 'na Rusi znaczy powinąć, obwinąć głowę panny młodej namiotką czyli oczepić ubiorem mężatek (...)', a także bezokoliczniki czepić, oczepić, cepić, ocepić, rusińskie powiwaty 'dopełniać obrzęd oczepin (ob.)'.

Ponadto Gloger rejestruje leksemy wianować 'dawać wiano w czasie wesela' oraz wiano 'posag; wyprawa należy do wiana a zwała się dawniéj u mniéj zamożnéj szlachty ochędóżka panieńska, po litewsku krajczys', które także mówią o obyczajach weselnych dawnej Polski.

Po uczcie weselnej następowały pokładziny, 'uroczyste prowadzenie nowożeńców poraz piérwszy do ich łożnicy, przy tańcach, muzyce, śpiéwach i stósownych obrzędach a niekiedy i oracyjach; (ob. Poduszkowy, Przepióreczka)'. W przeszłości, przed upowszechnieniem w Europie ślubów kościelnych, co nastąpiło po soborze trydenckim, czyli po roku 1563, pokładziny stanowiły bardzo istotny rytuał, ponieważ były jedynym koniecznym, a zarazem wystarczającym wymogiem potwierdzającym zawarcie małżeństwa. Z czasem przysięga małżeńska przed obliczem Boga wyparła tradycyjną formę zaślubin (Ciołek, Olędzki, Zadrożyńska 1976: 38). 
Z obrzędem pokładzin łączył się etap wesela nazywany przez Glogera swojewola '(nad Berezyną), chwila radosnego szału weselników, gdy po pokładzinach znajdą dowody dochowanego dziewictwa panny młodéj'.

Fazę końcową uroczystości weselnych stanowiły poprawiny 'ostatnia biesiada weselna $\mathrm{w}$ kilka dni po ślubie, zwana niekiedy potarzynami ${ }^{7}$. Nad Berezyną poprawiny zowią pierazów ${ }^{8}(. . .)^{\prime}$ oraz przenosiny 'znane w Krakowskiém przebabinami i odwozinami (...). Wyjazd młoduchy i przewiezienie jéj wiana do domu pana młodego z muzyką, pieśniami, obrzędami i ucztą na nowém gospodarstwie', które zależnie od tradycji regionalnych mogły być poprzedzone oddawinami 'uroczyste oddawanie wiana pannie młodéj przez jéj rodziców w Krakowskiém, co ma miejsce przed odwozinami (przenosinami) (...)'.

Podczas obrzędów weselnych używano różnych przedmiotów, o niektórych wspomina Gloger: dzieża, dzieza 'naczynie bednarskiéj roboty do chleba, na którém sadowią pannę młodą do rozplecin i oczepin. Matka wita powracających od ślubu z chlebem na wieku od dzieży', łożnica, łoźnica, łoznica 'łoże nowożeńców przy obrzędzie pokładzin, a w staréj polszczyźnie sypialnia państwa młodych. (...)', ręcznik, ręcnik, rucznyk 'biały podłużny kawał płótna z frendzlą na końcach, do niektórych obrzędów służący, w pieśniach weselnych wspominany i używany jako obrus'. Z krakowskim zwyczajem przenosin wiązał się z kolei przedmiot o nazwie macherzyna czyli 'nadęty pęcherz z kilkoma groszami wewnątrz, który w Krakowskiém w czasie przenosin kwoli wesołości wiozą z wianem panny młodéj do domu jéj męża, a by dzwonić po drodze niby worem piéniędzy'.

Całkiem liczną grupę wyrazów, zanotowanych w opracowaniu Glogera, tworzą nazwy stroju i nakrycia głowy panny młodej. Desygnaty, do których odnoszą się te określenia, pełniły ważną funkcję symboliczną podczas obrzędu oczepin: abglojme 'w staréj litewszczyźnie pewien ubiór głowy mężatek (namiotka, zawój, rąbek) wkładany uroczyście pannie młodéj, jako symbol zmiany jéj dziewiczego stanu. Był to więc rodzaj oczepin', czepiec, cepiec, cypiec, kornet, na Rusi czepeć i czypeć 'ubiór wyłącznie mężatek, grający główną rolę w obrzędzie ocze-

\footnotetext{
7 Potarzyna znaczy właściwie pojarmarcze, ostatni dzień po targu, jarmarku.

8 Pieriazow, wki (335). Zaprosiny poślubne; we Czwartek po ślubie świekier (ojciec pana młodego zaprasza do siebie rodziców synowéj i na odwrót (str. 310).
} 
pin (ob.)', namitka, namiotka, sierpanek, zawojka (nad Sanem) 'ubiór głowy mężatek na Rusi, którym dopełnia się obrzęd skrywania panny młodéj czyli oczepin. (...) (ob. Abglojme)', oczepek 'rodzaj czepca używanego wraz $\mathrm{z}$ namitkg w wielu okolicach Rusi przy skrywaniu (oczepinach)'. Ponadto do tej grupy nazw należy korona 'strój głowy panny młodéj ze świecideł, zastępujący w bardzo wielu okolicach zielony wieniec, do którego kształtem jest zbliżony i ma z nim jednakowe znaczenie godła dziewictwa (ob. Wieniec)', a także regionalnie uwarunkowane nazwy stroju głowy druhen: lotek 'strój głowy druchen pod Krakowem, składający się $\mathrm{z}$ trzech wstążek z tyłu upiętych; ob. Motyl', motyl 'strój głowy druchen pod Krakowem, składający się z sześciu wstążek kolorowych, upiętych nad czołem (....'.

W dawnej Polsce do ozdabiania włosów, stroju, a także wianków powszechnie używano kwiatów i ziół, których symboliczne znaczenie często było ważniejsze niż względy estetyczne. Gloger umieścił w słowniczku kilkanaście nazw, nierzadko uwzględniając preferencje lokalne przy wyborze i zastosowaniu konkretnych roślin, stąd warto je przywołać: barwinek (Vinca) 'ziele dziko w sadach rosnące używane przez druchny do wieńców i ubioru głowy, dla swéj zieloności, którą pod sniégiem zachowuje. Na Ukrainie bojarowie weselni zatykają barwinek u swych czapek', geranija (bodziszek) 'z białym kwiatem używana (między innymi) do wieńców i ubiorów (...)', jemiota (viscum album) 'jagód jéj używa lud piński do ozdoby rószczek zatykanych w korowaj pana młodego', kalina (Viburnum opulus) 'Jagody jéj czerwone są uprzywilejowaną ozdobą przy weselach, niby symbolem dziewiczéj krasy. Na Podlasiu, w Pińszczyźnie i wielu innych stronach zatykają je w korowaj a dziéwczęta w warkocze; pieśni Mazurów i Rusinów porównywają pannę młodą z krasną kaliną', lawenda (Lavendula spica) 'używana jest do wieńców weselnych, np. na Kujawach', mak (czerwony) 'zatykają bojarowie weselni na Ukrainie u czapek', nagietek 'Kolberg powiada, że „Turki dawniéj nagietki" używane są wraz z innymi kwiatami przy weselnym stroju na Kujawach (...)', rozmaryn (Rosmarinus) 'ziele do wieńców weselnych i ozdób używane', ruta (Ruta) 'w pieśniach: rutka, ruteńka, drobna ruteńka, ziele uprzywilejowane powszechnie do wieńców i bukietów weselnych, zachowujące w zimie zieloność jak barwinek, (ob. Barwinek, Lawenda, Rozmaryn, Mak i t.d.)', stokrótka (Bellis perennis) 'do wieńców i bukietów używana na Kujawach (...)', turek ob. Nagietek, wasilek (Centaurea cyanus) 'chaber, bławatek, modrak, wołoszek, służy czasem do ubioru głowy panny młodéj, gdy idzie za mąż 
w lecie', zimoziaj 'roślina leśna, wiecznie zielona, przez lud nadnarwiański do ozdób weselnych używana'.

Potrawy i posiłki weselne stanowiły ważny element obyczajowości weselnej. Poza kołaczem, a zwłaszcza korowajem, z którym wiązały się liczne rytualne czynności i zachowania, obrzędowy charakter miały także: wercz 'razem z korowajem obrzędowe ciasto weselne na Ukrainie', stuliny 'weselne ciasto u Rusinów podlaskich dawane nowożeńcom nazajutrz po pokładzinach, czyli po piérwszéj małżeńskiej nocy. Czy to nie ów chléb kładziony w wielu okolicach pod poduszki państwu młodym? Na Mazowszu w Czerskiém, na trzeci dzień po ślubie, państwo młodzi nosili w podarku do dworu kołacz zwany stulinami lub stólinami (...)', chléb weselny 'okrągły bochen razowca, niekiedy ozdobiony wyciskami, który przy stosownych pieśniach i pokłonach całują państwo młodzi wyjeżdżając do ślubu (np. w okolicach Białegostoku). We wsi Złotoryi na Podlasiu (nad Narwią) widziałem cztéry bochny weselnego chleba do tego obrzędu na tyluż rogach stołu położone', a także bażant 'pieczony kapłón lub kogut na uczcie weselnéj. Rusini podlascy przyrządzają go ze szczególnym obrzędem'. W słowniczku zostały odnotowany również nazwy byczek 'mała kukiełka, jakie wypiekają w niektórych okolicach na domowe uroczystości i wesela' oraz na wozy 'weselnicy na Podlasiu wyjeżdżający do ślubu dostają od matki panny młodéj jadło "na wozy” czyli na drogé'.

Gloger wymienia dwa podstawowe posiłki weselne: obiad (weselny), 'główna uczta godowa zwana bywa dużym obiadem, suchy obiad (nad Narwią), t.j. z zimnych przekąsek złożony, ma miejsce po pokładzinach i przenosinach' oraz śniadanie ' $w$ czasie wesel bywa: na wyjazd u pana młodego gdy z drużbami wyjeżdża przez ślubem domu panny młodéj, suche czyli zimne i kosmate'.

Nieodłącznym elementem wesela były tańce, które towarzyszyły weselnikom między innymi podczas niektórych obrzędów. Gloger wspomina o polonezie 'taniec u ludu wyłącznie weselny, głównie przy oczepinach i śpiéwie chmiela tańczony a rozmaicie w różnych okolicach nazywany, np. polski, wolny, powolny, wielki, chodzony, pieszy i odbijany', poduszkowym (taniec) czyli chmielowy, 'tańczony przez weselników po oczepinach przy śpiewie chmiela, gdy państwo młodzi mają iść do poduszki (ob. Pokładziny, Przepióreczka)', przepióreczce 'taniec ludu sandomiérskiego pląsany w nocy po oczepinach (...). Jest to więc zapewne tak zwany w innych stronach poduszkowy lub chmielowy (ob. taniec)', a także o kucharzu 'ku- 
charski taniec, tańczyć kucharza zwyczaj tańczenia z kucharką, która ucztę weselną przyrządzała, przyczém każdy z tańczących obdarza ją upominkiem piéniężnym'.

Spośród licznych pieśni, które śpiewano na weselu, w Glogerowych zapiskach zostały odnotowane następujące: chmiel 'pieśn symboliczna chmielu; weselnicy (żonaci i mężatki) „śsiéwają chmiela" przy oczepinach i pokładzinach, tak jak dawniéj śpiéwano go we dworach, przy cukrowéj wieczerzy, w sypialni państwa młodych', a także żartowne pieśni 'czyli pieśni weselne żartobliwe, szydne, jakich kwoli wesołéj uroczystości lud wiele posiada. Druchny wyśmiéwają niemi swachy, drużbów, swatów i nawzajem, a nikt obrazić się nie może za wolne żarty' oraz ładkaty rusińskie 'śpiéwać weselne pieśni (...)'.

Wśród zgromadzonych przez podlaskiego starożytnika wyrazów można odnaleźć takie, które nie mieszczą się w żadnej z wymienionych wyżej kategorii. Są to kunica, swadebnica, mordka, kopa licerska (rycerska) 'opłata składana dziedzicom w czasach poddaństwa od dziéwek wychodzących za mąż. (...) Danina ta dała niektórym badaczom powód do błędnego mniemania, jakoby $u$ nas znano juz cunagii, tę ochydę lennictwa zachodniego' oraz pojazd 'w niektórych stronach znaczy orszak weselny w drodze'.

W Glogerowym słowniczku zostały pomieszczone także nazwy, które - według podlaskiego etnografa - znane są z pieśni weselnych: Cisowy stót 'w pieśniach weselnych i innych nieraz wzmiankowany', Gronostaj (Mustella erminea), hornostaj 'w pieśniach Rusinów wspominany jest jako ubiór (szuba) panny młodéj', Najmilsy, najmilejsy, najmilsa, najmilejsa 'oblubieniec i oblubienica w pieśniach weselnych i miłosnych', Stulichna 'tak w jednéj pieśni weselnéj Mazurów zowié się kapusta (...)'.

Nazwy weselne... są interesującym, acz zapomnianym i niedocenionym zabytkiem polszczyzny XIX wieku, dokumentującym dawne, zróżnicowane regionalnie słownictwo weselne, stanowiące istotny wkład do dziejów polskiej leksykologii. Zbiór wyrazów zanotowanych przez Glogera to w dużej mierze archaizmy, ukazujące nie tylko fragment historycznej rzeczywistości językowej, ale także ukryty za słowami ważny wycinek życia rodzinnego i społecznego, nieistniejącego już w dawnym kształcie.

\section{BIBLIOGRAFIA}

Abraham W., 1925, Zawarcie małżeństwa w pierwotnym prawie polskim, Lwów. Bączkowska G., 1998, Korowaj, „Etnolingwistyka”, t. 1, 79-99. 
Bogucka M., 1994, Staropolskie obyczaje XVI-XVII wieku, Warszawa.

Ciołek T.M., Olędzki J., Zadrożyńska A., 1976, Wyrzeczysko. O świętowaniu w Polsce, Warszawa.

Kuchowicz Z., 1975, Obyczaje staropolskie XVII-XVIII wieku, Łódź.

Kwaśniewicz K., 1981, Zwyczaje i obrzędy rodzinne, w: Etnografia Polski. Przemiany kultury ludowej, t. 2, red. M. Biernacka, M. Frankowska, W. Paprocka, Wrocław, s. 89-126.

Potkański K., 1895, Postrzyżyny u Słowian i Germanów, „Rozprawy Wydziału Historyczno-Filozoficznego Akademii Umiejętności", Seria 2, t. 7, Kraków, s. $330-422$.

Świętek J., 1893, Lud Nadrabski (od Gdowa po Bochnię), Kraków.

Tymochowicz M., 2013(2014), Rola tradycyjnych obrzędów przejścia w podtrzymywaniu więzi rodzinnych i społecznych (na przykładach z obszaru woj. lubelskiego), „Rocznik Lubelskiego Towarzystwa Genealogicznego”, t. 5, s. 188-211.

\title{
THE FORGOTTEN WORLD OF WEDDING RITES IN OLD POLAND (ON THE BASIS OF THE GLOSSARY NAZWY WESELNE... BY ZYGMUNT GLOGER)
}

\begin{abstract}
Summary
The article depicts former, regionally diversified wedding lexis and helps to reconstruct rich nuptial rites hidden behind words, which were still very common in the second half of the 19th century and are now nearly completely forgotten. The resource material used as a basis of considerations herein is a nineteenth century glossary by Z. Gloger Nazwy weselne, wyrażenia i przedmioty używane przy godowych obrzędach ludu na przestrzeni byłej Rzplitej. The set of words recorded by Gloger mostly includes archaisms which not only show a fragment of a historical reality of the language but also reflect an important segment of a family and social life that does not exist anymore in the same old form.
\end{abstract}

Key words: dialect lexicography, 19th century, thematic vocabulary, wedding rites and customs, linguistic image of the world 